\title{
Performance Measurement in Local Governments: An Analysis of Organizational Factors
}

\author{
Vadira Damayanti \& Khoirul Aswar \\ Universitas Pembangunan Nasional Veteran Jakarta, Indonesia \\ khoirulaswar@upnvj.ac.id
}

\begin{abstract}
This study aims to determine the effect of organizational factors, namely decision-making authority, organizational objectives and targets, incentives and technical knowledge on performance measurement. The research sample is the Regional Apparatus of the City of East Jakarta Administration's Head of Subdivision and Planning Staff. The sampling technique uses the census sampling method. The data analysis method uses Structural Equation Modeling (SEM) using the Smart Partial Least Square application version 3.0. The findings reveal that technical knowledge has a considerable impact on performance measurement. Meanwhile, decision-making authority, organizational objectives and targets, and incentives have no significant effect on performance measurement. The findings of this study have implications for local governments to always maintain a code of ethics according to the standards for the preparation of LAKIP in order to realize effectiveness and efficiency so that government performance in the future can improve.
\end{abstract}

Keywords: Performance measurement, decision-making authority, organizational objectives and targets, incentives, technical knowledge, organizational factors, local government.

\section{Introduction}

The reform of state finances triggered by the economic crisis in 1998 required bureaucratic reform, marked by the issuance of TAP MPR No. XI/1998 concerning the Implementation of a State that is clean and free from KKN. As part of the government's attempts to foster more useful, clean, responsible, and successful governance, Presidential Instruction No. 7 concerning Government Performance Accountability was issued in 1999 (Pamungkas, 2012). The United Nations Development Program (UNDP) argues that accountability is an assessment of a process of implementing organizational activities/performance that must be accounted for whether it has been carried out according to agreed rules and standards. As well as an input for organizational leaders in improving organizational performance in the future. This instruction is supported by the issuance of Publication Decree of the Head of State Administration Agency (LAN) Number 239/IX/6/8/2003 regarding Guidelines for Preparation of Government Performance Accountability Reports. As a measure of government accountability to the public, the Government Agencies Performance Report (LAPKIN) offers information on the attainment of policy implementation results. Performance measurement in Indonesia has become a major part of public sector management reform (Podger \& Officer, 2004). Local government institutions or agencies are responsible for providing reports to the government above, namely the Ministry of Administrative Reform and Bureaucratic Reform (vertical accountability) and to the public (horizontal accountability) through the DPRD (Mardiasmo, 2004). The results of the evaluation of the Government Agency Performance Accountability System (SAKIP) at the district/city level show that the average evaluation of SAKIP in 2018 was $56.53 \%$ and in 2019 it was $58.85 \%$.

Where there was an increase of $2.32 \%$ from the previous year (menpan.go.id, 2020). Meanwhile, the results of the SAKIP evaluation at the provincial level showed that the average SAKIP evaluation in 2018 was $67.28 \%$ and in 2019 it was $69.31 \%$, which means an increase of $2.03 \%$. Although there was an increase in the average SAKIP score in both the Province and Regency/City, however, as many as 211 Regencies/Cities in Indonesia still received an average SAKIP score under category B. The Ministry of State Apparatus Empowerment and Bureaucratic Reform stated that the lower the category obtained, it means that the potential for budget ineffectiveness and inefficiency is getting bigger so this should be the focus of attention for the government in the future in an effort to improve their performance to increase budget effectiveness and efficiency. Performance measurement is the main key in realizing effectiveness, efficiency and accountability in the public sector (Spékle \& Verbeeten, 2009). Organizational factors are one of the aspects that determine the success of performance measurement (Cavalluzzo \& Ittner, 2004). Decision-making authority is one of the organizational factors that can affect performance measurement (Cavalluzzo \& Ittner, 2004). The existence of a delegation of decision-making authority makes it easier for management to make decisions quickly and develop creativity and innovation that creates a change (Putri \& Kamilah, 2019). Organizational objectives 
and targets also need to be considered for their effect on measuring organizational performance. According to the United States General Accounting Office (1997), overlapping organizational goals make it difficult to precisely identify the organization's strategic goals.

Which can make measuring organizational performance difficult. Verbeeten (2008) supports this by demonstrating that organizational objectives and targets have a major impact on Performance Measurement. In addition, performance measurement is also influenced by incentives. The reward and punishment system are believed to be used as an indicator of good performance (Kloot, 1999). According to the findings of Primarisanti and Akbar (2015)'s study, incentives have a considerable impact on performance measurement. Technical knowledge is also an important consideration. Technical knowledge is needed by members of the organization or employees in carrying out their duties. Technical knowledge enables the improvement of internal capabilities in understanding and using performance measurement (Sihaloho \& Halim, 2005). Previous research by Akbar et al. (2012) showed that technical knowledge affects performance measurement. This study refers to Syachbrani and Akbar (2020) and Aswar et al. (2020). As a differentiator for the study, with added another independent variable, namely incentives based on the recommendations of the previous study by Shafrizal et al. (2018). Based on the explanation above, further research is carried out to determine the factors that affect performance measurement.

\section{Literature Review and Hypothesis Development}

Institutional Theory: Complex phenomena and views within the scope of public sector organizations are mostly explained by institutional theory (Van Helden, 2005). This theory assumes that pressure on the organization will encourage the organization to conform to the right form of behavior because the legitimacy of an organization will be questioned if there are violations in the organization (DiMaggio \& Powell, 1983). Public organizations that gain legitimacy will tend to be similar to other public sector organizations (DiMaggio \& Powell, 1983). This homogeneity triggers stimuli or barriers to new practices in organizations, including accounting practices (Chang, 2007 in Khubiyati \& Arifin, 2016). The homogeneity process can be captured by the concept of isomorphism including coercive, mimetic, and normative isomorphism (DiMaggio \& Powell, 1983). Coercive isomorphism is created from the formal and informal pressures placed on an institution by other institutions in which they belong and the cultural expectations of the society in which the organization operates (DiMaggio \& Powell, 1983). In relation to the performance measurement system, the organization is obliged to consider the mandate of the central government through the submission of an annual performance report.

The existence of regulations imposed by the government puts pressure on organizations to adapt in accordance with what has been regulated by law. The decision encourages government organizations to adopt certain models, systems or practices because of pressure factors from outsiders called a coercive isomorphism. Normative isomorphism is closely related to professionalism. There are two aspects of normative isomorphism, namely legitimacy based on cognitive aspects obtained from tertiary institutions as well as formal educational background and the level of growth and influence of professional institutions that allow the rapid spread of new practices throughout the organization (DiMaggio \& Powell, 1983). Mimetic isomorphism occurs due to environmental uncertainty. The source of mimetic isomorphism comes from informational cascades. Where individuals or organizations that have inadequate information will make the same decisions as their predecessor organizations and ignore the information they have. According to DiMaggio and Powell (1983) argues that when organizational goals are perceived as ambiguous, technology cannot be understood and uncertainty occurs, this will encourage organizations to imitate other organizations.

Performance Measurement: Performance measurement is the main key in realizing effectiveness, efficiency and accountability in the public sector (Speklé \& Verbeeten, 2009). However, there are often problems in implementing performance measurement, namely during the development process and using the results from the implementation of performance measurement. Organizational variables are one aspect that influences the success of performance measurement (Cavalluzzo \& Ittner, 2004). The first organizational factor is decisionmaking authority. Decision-making authority is a situation in which a person has the authority to make decisions with predetermined conditions to achieve the organization's strategic goals (Cavalluzo \& Ittner, 
2004). Previous research related to decision-making authority conducted by Cavalluzzo and Ittner (2004) as well as Putri and Kamilah (2019) showed that decision-making authority has a significant influence on performance measurement. Meanwhile, Yowi (2011) in East Sumba Regency and Parwoto and Halim (2020) in Yogyakarta Special Region Province shows that decision-making authority does not have a significant impact on performance measurement. Then, the next factor is organizational objectives and targets. Organizational goals are defined as the implementation of an organization's mission statement that includes the expected results with a predetermined time (Pabeno et al., 2016). Organizational goals are an explanation of the organizational goals.

To be achieved or within a monthly, semi-annual or annual period (Pabeno et al., 2016). Previous research that examines this factor by Verbeeten (2008) shows that organizational goals and objectives have a significant impact on performance measurement. Meanwhile, Pabeno et al. (2016) in Jayapura City and Syachbrani and Wijaya (2020) at the Directorate General of Budget, Ministry of Finance of the Republic of Indonesia shows that organizational goals and objectives do not have a significant impact on performance measurement. Then, another factor, namely incentives are rewards related to performance and gain sharing, as profit sharing to employees for increasing productivity or decreasing costs (Rivai, 2009: 766 in Rochmat et al., 2013). Previous research that investigated the incentive factor, namely Julnes and Holzer (2001) in the United States which explained that incentives have a significant impact on performance measurement. Meanwhile, Specle and Verbeteen (2013) and Khaeruddin and Aditya (2020) states that incentives do not have a significant impact on performance measurement. Finally, Employees' technical knowledge is the knowledge they need to perform their jobs (Aswar et al., 2020). Akbar et al. (2012) show that technical knowledge influences performance measurement.

Hypothesis and Conceptual Framework: The development of hypotheses related to organizational factors in this study is formulated as follows:

Effect of Decision-Making Authority on Performance Measurement: Delegation of decision-making can develop creativity so as to make the determination of a decision faster (Primarisanti \& Akbar, 2015). A person who is given the authority is required to be professional in making decisions and must be responsible for the decisions he chooses, whether they are in line with the objectives. As a result, decision-making delegation is a factor that influences performance responsibility. This is due to the fact that normative isomorphism occurs. Managers feel that putting in place a performance measurement system will help them make better decisions, thus they are motivated to employ performance metrics. Related research conducted by Cavalluzzo and Ittner (2004) and Primarisanti and Akbar (2015) shows that performance measurement is influenced by decisionmaking authority.

H1: Decision-making authority has a significant effect on performance measurement.

Effect of Organizational Objectives and Targets on Performance Measurement: According to Sihaloho and Halim (2005) that organizational goals are agreements about the goals of each program and activity to be implemented to realize performance goals so that this goal orientation allows organizations to adopt performance measures. The performance will be better when there are clearer and more consistent goals, according to Verbeteen (2008), because it is easier to monitor performance when goals are explicit. However, determining the organization's mission, goals, and strategies requires involving a variety of stakeholders with varying choices and interests, making it difficult for the government to determine goals and objectives. As a result, local governments will tend to imitate the goals and objectives of other local governments that are more successful (DiMaggio \& Powell, 1983). This is the result of mimetic isomorphism. Wang (2002) and Verbeeten (2008) show that performance measurement is influenced by organizational objectives and targets.

H2: Organizational objectives and targets have a significant effect on performance measurement.

Effect of Incentives on Performance Measurement: The reward and punishment systems are believed to be used as an indicator of good performance (Kloot, 1999). The provision of incentives due to organizational policies to improve the performance of each individual for the better and reflects normative isomorphism. Providing incentives by the organization as an effort to meet the needs of employees because basically, every individual has an interest in their welfare (Indudewi \& Nafasita, 2012). Providing incentives to employees 
will improve the performance and productivity of an organization. Primarisanti and Akbar (2015) show that performance measurement is influenced by incentives.

H3: Incentives have a significant effect on performance measurement.

Effect of Technical Knowledge on Performance Measurement: Technical knowledge is defined as a need for organizational members to support the implementation of their duties (Aswar et al., 2020). The existence of technical knowledge allows for increased understanding and internal capacity of stakeholders in using performance measurement (Julnes and Holzer, 2001; Sihaloho and Halim, 2005 in Akbar et al., 2012). In Indonesia, many initiatives have been made to expand the expertise of government personnel and authorities, ranging from technical training to formal degree programs (Akbar et al., 2012). This perspective reflects normative isomorphism. In accordance with the results of Akbar et al. (2012) which suggests that performance measurement is influenced by technical knowledge.

H4: Technical knowledge has a significant effect on performance measurement.

Figure 1: Research Framework

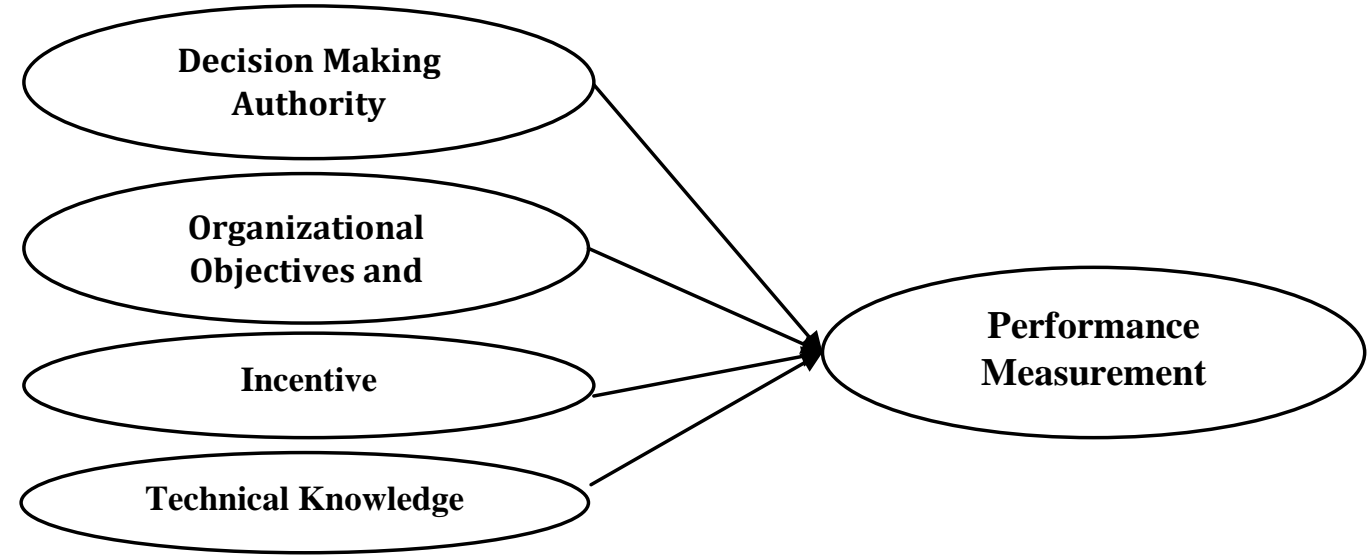

\section{Research Methodology}

The population of this study is the State Civil Apparatus in the East Jakarta City Administration's Regional Apparatus Organization. The head of the planning sub-section and the planning personnel responsible for LAPKIN in the Regional Apparatus Organization of the East Jakarta City Administration were included in the study's sample. The total sample in this study is 45 respondents. The sampling technique used is census sampling. Primary data, which is data acquired directly from the field, is the sort of data used in this study (Sekaran \& Bougie, 2017). This study uses a survey as a method of data collection and a questionnaire as a means of data collection. The questionnaire was distributed via WhatsApp in the form of a google form link. The measurements of each variable are presented in table 1. A structural equation model (SEM) is used to process the data in this research, and partial least square (PLS) is data analysis software that can process a small amount of data.

Table 1: Variables Measurement

\begin{tabular}{|c|c|c|c|c|}
\hline Variable & Indicator & Scale & $\begin{array}{l}\text { No of } \\
\text { Statements }\end{array}$ & Source \\
\hline $\begin{array}{l}\text { Performance } \\
\text { Measurement }\end{array}$ & $\begin{array}{l}\text { Inputs, outputs, outcomes, costs, benefits, } \\
\text { impacts, and processes. }\end{array}$ & Likert & 7 & $\begin{array}{l}\text { Aswar et al. } \\
(2020)\end{array}$ \\
\hline $\begin{array}{l}\text { Decision } \\
\text { Making } \\
\text { Authority }\end{array}$ & $\begin{array}{l}\text { My office manager has decision-making } \\
\text { authority that is intended to achieve the } \\
\text { strategic goals of the organization }\end{array}$ & Likert & 1 & Yowi (2011) \\
\hline $\begin{array}{l}\text { Organizational } \\
\text { Objectives and } \\
\text { Targets }\end{array}$ & $\begin{array}{l}\text { Mission of Regional Apparatus Organizations } \\
\text { (OPD), OPD targets follow political } \\
\text { developments, OPD targets change according }\end{array}$ & Likert & 3 & $\begin{array}{l}\text { Wijaya and } \\
\text { Akbar (2013) }\end{array}$ \\
\hline
\end{tabular}


to community demands.

\begin{tabular}{|c|c|c|c|c|}
\hline Incentive & OPD provides incentives for performance & Likert & 2 & Primarisanti \\
\hline & $\begin{array}{l}\text { improvement and OPD provides incentives for } \\
\text { risk-taking }\end{array}$ & & & $\begin{array}{ll}\text { and } & \text { Akbar } \\
(2015) & \end{array}$ \\
\hline $\begin{array}{l}\text { Technical } \\
\text { Knowledge }\end{array}$ & $\begin{array}{l}\text { Receive training on performance measures, } \\
\text { receive published information on performance } \\
\text { measures, involve experts in developing } \\
\text { performance measures }\end{array}$ & Likert & 3 & $\begin{array}{l}\text { Aswar et al. } \\
(2020)\end{array}$ \\
\hline
\end{tabular}

\section{Results and Discussion}

The process of distributing the questionnaires was assisted by the Head of the Administrative Subdivision and his staff. Data collection was carried out for 41 days with a questionnaire return rate of $72.6 \%$.

Table 2: Statistic Descriptive

\begin{tabular}{lll}
\hline Variable & Mean & Std. Deviation \\
\hline Performance Measurement (PM) & 4,29 & 0,70 \\
Decision Making Authority (DMA) & 4,42 & 1,19 \\
Organizational Objectives and Targets (OOT) & 3,00 & 1,28 \\
Incentive (ICT) & 3,58 & 1,14 \\
Technical Knowledge (TK) & 4,16 & 0,78 \\
\hline
\end{tabular}

Table 2 shows the results of statistical tests where the mean value of the performance measurement is 4.29 with a standard deviation of 0.70 . Then, the decision authority making has a mean value of 4.42 with a standard deviation of 1.19. The mean and standard deviation of organizational objectives and targets, respectively, are 3.00 and 1.28. Furthermore, the mean and standard deviation of the incentive are 3.58 and 1.14 , respectively. Lastly, technical knowledge has a mean value of 4.16 and a standard deviation of 0.78 . Each of the mean and standard deviation values contained in each variable illustrates that the mean value > standard deviation value. That is, this study describes a fairly high level of homogeneity and shows the existence of an average value that can describe the actual data.

Table 3: Convergent Validity and Reliability

\begin{tabular}{llll}
\hline Variable & AVE & Composite Reliability & Cronbach's Alpha \\
\hline PM & 0,514 & 0,879 & 0,843 \\
DAM & 1,000 & 1,000 & 1,000 \\
OOT & 0,532 & 0,764 & 0,671 \\
ICT & 0,779 & 0,875 & 0,724 \\
TK & 0,736 & 0,893 & 0,819 \\
\hline
\end{tabular}

Source: Own Calculations

The recommended AVE value is more than 0.50 (Hair, Sarstedt, Hopkins \& Kuppelwieser, 2014). Based on the results in table 4 . Each variable has an AVE value above 0.50 meaning that all variables in this research are declared valid. Then the recommendation value in Cronbach's alpha is more than 0.60 . The value of Cronbach's alpha in each variable is greater than 0.60 , as seen in the table above. As a result, all variables in this study had a high level of dependability for each statement. Furthermore, it can be seen from the table above that the composite reliability value for all constructs or statements is more than 0.70 , meaning that all constructs or statements in this research are estimated to have met the criteria. 
Table 4: Discriminant Validity Fornell-Lacker Criterion

\begin{tabular}{|c|c|c|c|c|c|}
\hline & Incentive (ICT) & $\begin{array}{l}\text { Decision } \\
\text { Making } \\
\text { Authority } \\
\text { (DMA) }\end{array}$ & $\begin{array}{l}\text { Technical } \\
\text { Knowledge (TK) }\end{array}$ & $\begin{array}{l}\text { Performance } \\
\text { Measurement } \\
\text { (PM) }\end{array}$ & $\begin{array}{l}\text { Organizational } \\
\text { Objectives and } \\
\text { Targets (OOT) }\end{array}$ \\
\hline ICT & 0,882 & & & & \\
\hline DMA & 0,226 & 1,000 & & & \\
\hline $\mathrm{TK}$ & 0,469 & 0,544 & 0,858 & & \\
\hline PM & 0,380 & 0,415 & 0,677 & 0,717 & \\
\hline OOT & $-0,012$ & $-0,081$ & $-0,128$ & $-0,162$ & 0,729 \\
\hline
\end{tabular}

Source: Own Calculations

Based on the results of the Fornell-Lacker Criterion test, the discriminant validity value of each variable is more than 0.60. Performance Measurement (PM) has a value of 0.717. The Decision-Making Authority (DMA) has a value of 1,000. Organizational Objectives and Targets (OOT) have a value of 0.729 . Then Incentive (ICT) has a value of 0.882 and Technical Knowledge (TK) has a value of 0.858 . These results illustrate that all constructs or statements of each variable are valid.

Table 5: PLS Path Algorithm and Bootstrapping

\begin{tabular}{llll}
\hline Relations & Path Coefficient & T Value & P Value \\
\hline ICT -> PM & 0,087 & 0,671 & 0,502 \\
DMA -> PM & 0,069 & 0,389 & 0,697 \\
TK - PM & 0,588 & 4,713 & 0,000 \\
OOT -> PM & $-0,079$ & 0,433 & 0,665 \\
\hline
\end{tabular}

Source: Own Calculations

The results in table 6 show that the coefficient value of the decision-making authority (DMA) path analysis is 0.069. This shows that decision-making authority has a positive relationship to performance measurement of 0.069 . The value of the $t$ count $t$ table is 0.3892 .021 , and the significance value is more than 0.05 , hence $\mathrm{H} \mathrm{A} 1$ is rejected, according to the results of the t-statistical test above. The reason for the rejection of this hypothesis was due to the limited authority for the preparation of LAPKIN in the LAPKIN preparation team. Each member of the team has the authority to provide input and analysis of the organization's performance. LAPKIN is made up of data on performance achievement, such as physical realization, budget realization, revenue target achievement, strategic goal achievement, and other targets with determined indications and values. The team's authority is confined to data presentation and analysis, regardless of whether or not the results are as predicted. This is because the preparation of LAPKIN has been regulated by law. Yowi (2011) in East Sumba Regency and Parwoto and Halim (2020) in Yogyakarta Province's Special Region complement the findings of this study, which reveal that decision-making authority has no substantial impact on performance assessment. The coefficient value of organizational objectives and targets (OOT) path analysis on performance measurement is -0.079 .

This means that organizational objectives and targets have a negative relationship with performance measurement. If the significance value is larger than 0.05 and the $t$-statistical test shows $t$ count $t$ table ebesars 0.4332 .021 , then "H2" is rejected. This indicates that organizational goals and objectives have little bearing on performance measurement. The results of this study are in line with Pabeno et al. (2016) in Jayapura City and Syachbrani and Wijaya (2020) at the Directorate General of Budget, Ministry of Finance of the Republic of Indonesia which shows that organizational objectives and targets do not have a significant impact on performance measurement. The reason for the rejection of this hypothesis is that the objectives of the OPD do not change following political developments on a regular basis. That is, political interests are not a source of uncertainty that affects the objectives of performance measurement in the public sector. This indicates that the institutional theory is not supported, namely mimetic isomorphism. Where local governments imitate other local governments that are better because of the uncertainty. Furthermore, the value of the path analysis coefficient on the incentive is 0.087 . This shows that incentives have a positive 
relationship to performance measurement. The results of the t-statistical test show that $t_{-}$count $<t_{-}$table is $0.671<2.021$ and the significance value is greater than 0.050 , then $H_{-} A 3$ is rejected.

This suggests that incentives have no discernible impact on performance evaluation. Incentives do not have a major impact on performance measurement, according to Specle and Verbeteen (2013) and Khaeruddin and Aditya (2020). The contributing factor is that most OPDs no longer provide incentives to ASN because their duties and work are part of their obligations as state servants. ASN has also been given a salary and income allowance by the government, so there is no longer any additional incentive. So that the reward indicator is no longer used in performance measures because it does not have a significant impact. Finally, the path analysis coefficient on technical knowledge (TK) is 0.588 and is positive. The results of the t-statistical test show that t_count $>t_{\text {_table is }} 4.713>2.021$ and the significance value is less than 0.05 , then H_A4 is accepted. This implies that technical knowledge has a substantial impact on performance measurement. Akbar et al. (2012) reinforce this conclusion by demonstrating that technical knowledge has an impact on performance measurement. Because technical performance assessment training is normally directed at lower managerial levels, such as the Head of the Planning Subdivision, the hypothesis in this study was accepted. Training related to technical matters is more relevant to lower-level managers than middle and upper-level managers. This is because lower-level managers manage and are responsible for providing direct direction to staff. So, they need technical skills and abilities in leading and organizing staff.

\section{Conclusion}

After a series of tests, decision-making authority, organizational objectives and targets, and incentives were discovered to have no meaningful impact on performance measurement. Meanwhile, technical knowledge has a significant effect on performance measurement. The contribution of this study is to head of OPD planning expected to maintain the standard of the LAKIP and be responsible for every task that has been entrusted to maintain public trust. This research makes a number of recommendations that might be valuable to future researchers who want to expand their research by including other factors that affect performance measurements, such as internal responsibility, productivity, and metric difficulty. For the head of the planning sub-section of the East Jakarta administration city OPD, it is hoped that they will be able to maintain behavior and adhere to the code of ethics in accordance with management standards in the preparation of LAKIP and be responsible for each task that has been entrusted to maintain public trust. The next study added the population, not only in the East Jakarta Administration City OPD. Then, the further study also can expand the object and respondents so that the results of further research are expected to be more valid.

\section{References}

Akbar, R., Pilcher, R. \& Perrin, B. (2012). Performance measurement in Indonesia: The case of local government. Pacific Accounting Review, 24(3), 262-291. doi:10.1108/01140581211283878

Aswar, K., Putri, L. E. \& Ermawati, E. (2020). The effect of organizational factors on performance measurement in Indonesian local governments. International Journal of Economics and Business Administration, 8(4), 122-131. doi:10.35808/ijeba/574

Cavalluzzo, K. S. \& Ittner, C. D. (2004). Implementing performance measurement innovations: Evidence from the government. Accounting, Organizations and Society, 29(3), 243-267. doi:10.1016/S03613682(03)00013-8

DiMaggio, P. J. \& Powell, W. W. (1983). The iron cage revisited: Institutional isomorphism and collective rationality in organizational fields. American Sociological Review, 48(2), 147-160. doi: $10.2307 / 2095101$

Hair, J. F., Sarstedt, M., Hopkins, L. \& Kuppelwiese, V. G. (2014). Partial least squares structural equation modeling (PLS-SEM): An emerging tool in business research. European Busniess Review, 26(2), 106121.

Indudewi, D. \& Nafasita, F. (2012). Pengaruh sasaran jelas dan terukur, insentif, desentralisasi, dan pengukuran kinerja terhadap kinerja organisasi (studi empiris pada SKPD dan BUMD Kota Semarang). Jurnal Dinamika Sosial Budaya, 14(1). 
Julnes, P. d. \& Holzer, M. (2001). Promoting the utilization of performance measures in public organizations: An empirical study of factors affecting adoption and implementation. Public Administration Review, 61(6), 693-708. doi:10.1111/0033-3352.00140

Khaeruddin, F. \& Aditiya, R. (2020). Evaluasi implementasi sistem pengukuran kinerja instansi pemerintah daerah. ASSETS, 10(2), 195-209.

Khubiyati, A. \& Arifin, J. (2016). Analisis pengaruh faktor institusional terhadap minat adopsi sistem informasi akuntansi keuangan daerah. Simposium Nasional Akuntansi XIX.

Kloot, L. (1999). Performance measurement and accountability in Victorian local government. The International Journal of Public Sector Management, 12(7), 565-583. doi:10.1108/09513559910308039

Mardiasmo. (2004). Akuntansi sektor publik. Yogyakarta: Andi Offset.

Menpan.go.id. (2020). Pemda berhasil hemat anggaran SAKIP. From: https://menpan.go.id/site/beritaterkini/pemda-berhasil-hemat-anggaran-dengan-sakip (accessed: March 20, 2021)

Pabeno, J., Layuk, P. K. \& Rante, A. (2016). Determinan penggunaan sistem pengukuran kinerja sektor publik. Jurnal Akuntansi \& Keuangan Daerah, 11(1), 13-28.

Pamungkas, D. (2012). A growth comparison of Ongole and European cross cattle kept by smallholder farmers in Indonesia. In Proceeding of the 15th Asian-Australasian Association of Animal Production (AAAP) Animal Science Congress, Bangkok, Thailand.

Parwoto. \& Halim, A. (2020). The effects of organizational and political factors on the development of performance measurement systems (PMS) of local government institutions. Journal of Accounting and Investment, 21(2), 217-239. doi:10.18196/jai.2102146

Podger, 0. \& Perwira. (2004). Review of Legislation on Planning and Budgeting.

Primarisanti, H. \& Akbar, R. (2015). Factors influencing the success of performance measurement: evidence from local government. Journal of Indonesian Economy and Business, 30(1), 56-71.

Putri, G. E. \& Kamilah, F. (2019). Pengaruh faktor-faktor teknis dan organisasional terhadap pengembangan sistem pengukuran kinerja (studi pada opd kota pekanbaru). Jurnal Ilmiah Ekonomi dan Bisnis, 16(1), $10-18$.

Rochmat, K. B., Hamid, D. \& Hakam, M. S. (2013). Pengaruh insentif terhadap motivasi dan kinerja. Jurnal Administrasi Bisnis (JAB), 1(1), 19-27.

Sekaran, U. \& Bougie, R. (2017). Metode penelitian untuk bisnis. Jakarta: Salemba Empat.

Shafrizal, A., Taufik, T. \& Nasir, A. (2018). Pengaruh faktor organisasional dan karakteristik Individu terhadap akuntabilitas kinerja melalui sistem pengukuran kinerja. Jurnal Ekonomi, 26(4), 102-115.

Sihaloho, F. L. \& Halim, A. (2005). Pengaruh faktor-faktor rasional, politik dan kultur organisasi terhadap pemanfaatan informasi kinerja instansi pemerintah daerah. SNA, 8, 774-790.

Speklé, R. F. \& Verbeeten, F. H. (2009). The use of performance measurement systems in the public sector: effects on performance. Management Accounting Research, 25(2), 1-42. doi:10.2139/ssrn.1162242

Speklé, R. F. \& Verbeeten, F. H. (2013). The use of performance measurement systems in the public. Management Accounting Research, 1-16. doi:10.1016/j.mar.2013.07.004

Syachbrani, W. \& Akbar, R. (2020). The influence factors of the development of performance measurement systems in Indonesia's central government. IEOM Society International.

Undp.org. (2021). Accountability. From: https://www.undp.org/accountability (accessed: March 16, 2021)

Vanhelden, G. J. (2005). Researching public sector transformation: The role of management accounting. Financial Accountability and Management, 21(1), 99-133.

Verbeeten, F. H. (2008). Performance management practices in public sector organizations: Impact on performance. Accounting, Auditing \& Accountability Journal, 21(3), 427-454.

Wang, X. (2002). Assessing performance measurement: A study of US local government. Public Performance and Management Review, 26, 26-43.

Wijaya, A. H. \& Akbar, R. (2013). The influence of information, organizational objectives and targets, and external pressure towards the adoption of performance measurement systems In public sector. Journal of Indonesian Economy and Business, 28(1), 62-83.

Yowi, L. R. (2011). The correlation among the factors of implementation, the system development, and the result of performance measurement system: A study conducted in the regency of Sumba Timur. Journal of Indonesian Economy and Business, 26(3), 371-388. 